AWEJ for Translation \& Literary Studies, Volume3, Number2.May 2019

DOI: http://dx.doi.org/10.24093/awejtls/vol3no2.6

Pp.56-65

\title{
Unraveling the System of Representation of the Colonizer in E. M. Forster's A Passage to India (1924) and Louis Bertrand's La Cina (1901)
}

\author{
Fatima BENSIDHOUM \\ English Department \\ Faculty of Letters and Languages, University of Mouloud Mammeri \\ Tizi Ouzou, Algeria
}

\begin{abstract}
The main focus of this research paper is to study one of the key concepts of postcolonial critical theory which is "Identity and Representation". It is based upon a textual reading and analysis of two texts as representatives of colonial literature written about British-India and French-Algeria, namely A Passage to India by E.M. Forster and La Cina by Louis Bertrand. Relying on Albert Memmi's foundational postcolonial theory developed in his The Colonizer and the Colonized, we assume that both texts obey and reflect a similar ideological discourse. The narratives are revealed to operate through a complex system which tends to (re)fashion and to (re)mold the identity of both the colonizer and the colonized. We demonstrate that Forster and Bertrand shape the main characters into two types which Memmi labels as: 'the Colonizer who Accepts' and 'the Colonizer who Refuses'. We have also showed that the writers though belonging to different imperial powers and writing in two different languages, they could not but adhere and support the colonial practices of their countries. What comes also of this study is that Forster, though most often known for his Liberalism, vehicles a racial discourse which accounts for the superiority of the British colonizer. Bertrand is much more racist and jingoist, his attitudes are reminders of what Achebe said about Conrad; 'a bloody racist'.
\end{abstract}

Key Words: A Passage to India, colonial discourse, E.M. Forster, identity, La Cina, Louis Bertrand, representation, 'the colonizer who accepts', 'the colonizer who refuses.'

Cites as: BENSIDHOUM, F. (2019). Unraveling the System of Representation of the Colonizer in E. M. Forster's A Passage to India (1924) and Louis Bertrand's La Cina (1901). Arab World English Journal for Translation \& Literary Studies, 3 (2) 56-65.

DOI: http://dx.doi.org/10.24093/awejtls/vol3no2.6 